\begin{tabular}{ll}
\hline & Jurnal Sains Materi Indonesia \\
Homepage: ${ }_{\text {http://jusami.batan.go.id }}$ & $\begin{array}{l}\text { Akreditasi Nomor: 21/E/KPT/2018 } \\
\text { Tanggal 9 Juli 2018 } \\
\text { ISSN 1411-1098 } \\
\text { E-ISSN 2614-087X }\end{array}$ \\
\hline
\end{tabular}

\title{
MORPHOLOGY AND TENSILE PROPERTIES OF PVA/SNAIL MUCIN NANOFIBER MEMBRANES
}

\author{
Aris Widyo Nugroho ${ }^{1}$, Imam Nur Sholeh ${ }^{1}$ and Harini Sosiati ${ }^{1}$ \\ ${ }^{1}$ Department of Mechanical Engineering, Faculty of Engineering - UMY \\ Jl. Lingkar Selatan, Yogyakarta 55183 \\ E-mail: ariswidyo.nugroho@umy.ac.id
}

Received: 26 April 2018

Revised: 20 May 2018

Accepted: 17 July 2017

\begin{abstract}
MORPHOLOGY AND TENSILE PROPERTIES OF PVA/SNAIL MUCIN NANOFIBER MEMBRANES. Snail mucin has been widely known to contain agents with wound healing properties. A preliminary research with regard to the potential to manufacture composite nanofibrous membranes of polyvinyl alcohol (PVA) and snail mucin (SM) by the electrospinning technique for wound dressing applications has been conducted. The effect of SM concentration on the morphology and tensile properties of PVA/SM nano membrane has been investigated. The PVA/SM solutions with various concentration of SM $(0 \%, 2 \%, 4 \%$, dan $6 \%)(\mathrm{w} / \mathrm{v})$ were electrospun at the optimized process parameters. The morphology nanofiber membranes was observed by scanning electron microscopy and the average diameters of prepared nanofibers was determined by image analysis technique. The tensile test was conducted to examine the tensile properties of the nanofiber membranes being prepared according to ASTM D882. The PVA/SM nanofibre membrane possessing the tensile strength and tensile strain ranging between 3.48-5.37 MPa and 101.25-157.13\%, respectively were

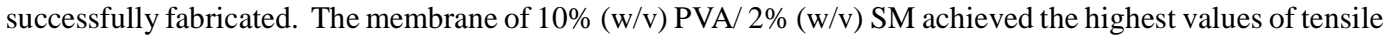
strength. This phenomenon has been associated to the uniformity of fiber size diameter distribution within the membranes. It was expected that further optimization of the processing would allow development of the tensile properties compatibility requirement with this being the subject of future work by the authors.
\end{abstract}

Keywords: Electrospinning, Nanofibres, PVA, Snail mucin, Wound dressing

\begin{abstract}
ABSTRAK
MORFOLOGI DAN SIFAT TARIKMEMBRAN SERAT NANO POLIVINILALKOHOL/LENDIR BEKICOT. Lendir bekicot telah banyak dilaporkan mengandung elemen yang bermanfaat dalam penyembuhan luka. Penelitian ini dilakukan untuk mengetahui pengaruh konsentrasi lendir bekicot (SM) pada morfologi dan sifat tarik membran komposit serat nano polivinil alkohol/lendir bekicot (PVA/SM) yang dihasilkan dengan teknik elektrospinning untuk aplikasi pembalut luka. Larutan PVA/SM dengan berbagai konsentrasi SM $(0 \%, 2 \%, 4 \%$, dan $6 \%)(\mathrm{w} / \mathrm{v})$ di-elektrospinning pada parameter proses optimal. Morfologi membran nanofiber diamati dengan menggunakan mikroskop elektron. Diameter rata-rata nanofibers diukur dengan teknik analisis citra. Sifat tarik membran serat nano diperoleh dengan melakukan uji tarik menurut standard ASTM D882. Hasil penelitian menunjukkan bahwa membran serat nano PVA/SM memiliki kekuatan tarik antara 3,48 MPa hingga 5,37 MPa dan regangan tarik sebesar 101,25 \% hingga 157,13\%. Nilai kekuatan tarik tertinggi dicapai oleh membran dengan komposisi 10\% (w/v) PVA/2\% (w/v) SM. Pada komposisi tersebut diperoleh membran serat nano dengan keseragaman diameter ukuran serat paling tinggi dengan ukuran diameter serat yang paling kecil $(348 \pm 32.62 \mathrm{~nm})$. Diharapkan optimasi proses lebih lanjut akan mendapatkan kompatibilitas sifat tarik yang dapat digunakan untuk aplikasi biomedis.
\end{abstract}

Kata kunci: Elektrospinning, Nanofiber, PVA, Lendir bekicot, Pembalut luka 


\section{INTRODUCTION}

Wound healing is critical to bring back skin integrity for protecting us from water loss and against pathogens and harmful assault. Nowadays, an ideal treatment give attention on dressings that should prevent microbial inûltration, maintain a balanced moisture and gas exchange environment, deliver antibacterial, stimulate cell proliferation in the wound and possess good biocompatibility [1]. To provide those properties, numerous researches have been carried out to develop various wound dressing materials. Among those nanoscale materials especially nanofibrous membrane fabricated by electrospinning technique have been reported presenting their successful application in tissue repair and wound management due to their desirable properties, such as high surface area to volume ratio, sufficient mechanical stability and high interconected porosity [2]. In addition this technique is a simple, adaptable, cost effective and versatile process [3]. Principally, electrospinning process involves application of a high electrostatic field to a polymer solution, leading to the ejection of a continuous jet strand from the spinneret towards a grounded aluminum collector.

A number of polymers have been electrospun into nanoûbers for tissue engineering applications. Natural biopolymer such as chitosan, cellulose hyaluronic gelatin,cellulose, collagen and silk fibroin have been electrospun for localized drug delivery or wound healing [4]. The major drawbacks associated with the use of protein based-polymers are their low mechanical stiffness and rapid degradation rate in vivo. On the other hand, the functions and properties (e.g., porosity, degradation time, and mechanical characteristics) of synthetic polymers can be tailored by modifications in the synthesis processes according to specific requirements and applications in order to overcome many of the presented shortcomings of natural origin polymers.

Synthetic polymers commonly used for wound healing applications include poly(ethylene oxide) (PEO), poly(lactide) (PLA), polye( $\varepsilon$-caprolactone) (PCL), polyurethane (PU), polyvinylpyrrolidone (PVP), poly(lactic-co-glycolic acid) (PLGA) and poly(vinyl alcohol) (PVA)[4]. PVA is a well-known, biologically friendly, biodegradable polymer because of its excellence properties such as biocompatibility, no carcinogenicity, nontoxicity, and appropriate mechanical properties. Owing to its flexibility and swelling capability in an aqueous medium, PVA has been extensively studied as a wound dressing $[3,5]$.

Antibacterial agents-inorganic, organic or metallic-should also be incorporated into the polymeric nanoûbers to prevent bacterial colonization and subsequent wound infection [6]. Among the antimicrobial agents that are available, silver- nanoparticles (AgNPs) have been reported to be highly eûective antimicrobial agents when treating infectious wounds [7]. However the application of chemical compounds for wound healing sometimes makes a toxic effect in in vitro studies. Alternatively, researchers have been inspired by nature for antibacterial agents. One of them is snail mucin (Achatinafulica). Snails produce mucin abundantly in their mucus secretion often referred to as slime, which have been reported to contain antimicrobial proteins [8].

In addition, the essential substances contained in the snail mucin involve glycosaminoglycans which play role in cell regeneration and growth and proteins which have important biological functions, including as a bacterial protein (enzyme) binding receptor [9]. Meilany et al., (2015) [10] has synthesized composite based on alginate-polyvinyl alcohol with addition of snail (Achatinafulica) by electrospinning method. Whilst the membranes have been successfully fabricated with fiber size diameter in range of nano-micrometers, there was no new functional group observed by FT-IR due to the addition of the snail mucin. Beads were found in membrane being produced.. Another research used snail powder as additives for fabrication nanofibres by electrospinning [11]. Unsmooth nanoûber was obtained with average size diameter in the range of $255 \mathrm{~nm}$ and the fiber have high acid proof and alkali proof properties. However, those researches have not revealed their tensile properties.

Up to now, the development of nanofibre membrane of PVA/SM is still rare. Therefore this study demonstrated the effect of SM concentration on fabrication of the nanofibrous PVA/SM membrane by electrospinning technique and their characterization including morphology and the tensile properties with the expected tensile properties approaching the commercial wound dressing.

\section{EXPERIMENTAL METHOD}

PVA solution $(10 \% \mathrm{w} / \mathrm{v})$ were prepared by dissolving PVA gohsenol which is commercially obtained (10 gram) in $100 \mathrm{ml}$ of distilled water at $80^{\circ} \mathrm{C}$, and then allowing the solutions to stir for 4 hours. The snail mucin was collected from the selected snails by taking it out from the tip of snails shell being cut and leaved them alive. The mucin was then filtered to remove the contaminants and was blended with the PVA solution at $0,2,4$ and $6 \%$, (w/v). Following this, the blended solutions were continuously stirred with magnetic stirrer at ambient temperature for 3 hours.

Before electrospinning process was conducted, processing parameters including Tip to Collector Distance (TCD) and voltage (V) were optimized in spinneret diameter of $0.6 \mathrm{~mm}$ in order to attain the suitable processing parameter. Afterwards, the blended solution were taken up in $5 \mathrm{ml}$ syringe equipped with a 20 gauge, 
stainless steel spinneret at the nozzle and located into the electrospinning machine which was developed by the research group.

The spinneret was connected to emitting electrode of positive polarity of the high voltage device. The voltage was set up at optimized value of $15 \mathrm{kVand}$ was electrospun at room temperature. The nanoûbres were collected as spun on an aluminum sheet that was wrapped on a flatten collector. The solution feed was driven by a syringe pump with a controlled ûow rate of approximately $0.025 \mathrm{~mL} /$ minute. The TCD was fix at optimized value of $16.5 \mathrm{~cm}$. The process duration was conducted for $3 \mathrm{~h}$ for each concentration of PVA/SM solutionto provide membrane with desirable thickness. The morphology of the nanoûbre membranes was observed using scanning electron microscopy (SEM, JSM-6510LA). Randomly selected areas of the ûbres were cut into squares and coated with a thin layer of gold. The average diameter of the nanoûbre membranes was analyzed by randomly measuring the diameters of the nanoûbres at 100 different points each of 2 micrograph SEM images by using the image analysis software (ImageJ, National Institutes of Health, USA). The tensile properties of the nanoûbre membrane was evaluated using Universal Testing Machine (Zwick Z0.5 Germany) with a $100 \mathrm{~N}$ load cell equipped, a gauge length of $20 \mathrm{~mm}$ and strain rate of $5 \mathrm{~mm} / \mathrm{min}$. The tensile testing specimens were prepared in accordance to ASTM D882.

\section{RESULTS AND DISCUSSION}

The SEM images of PVA/SM nanofibre membrane with different concentration are depicted in Figure 1 showing the morphology the membrane. Generally, the SEM micrographs demonstrated that randomly oriented as-spun nanofibre exhibited bead-free, smooth surface with almost uniform diameter along their lengths and the diameters of the composite nanofibre were measured to be in the range of $200-900 \mathrm{~nm}$.

The nanofibre membrane show high interconnecting porosity. However, the nanofibre without SM addition which may possess the highest viscosity of the polymer solution (Figure 1(a)) shows the exception. It was observed that the solvent may incompletely evaporate leading to form the nanofibres in non-uniform shape and size diameter. The SM addition may reduce the viscosity which causes the solvent to evaporate more easily. As known that a number of processing parameters affected the diameter and morphology of the nanofibers and the polymer solution with appropriate viscosity, surface tension and conductivity allow to fabricate an acceptable nanofibre [12].

From Figure 1, the distribution of nanofiber diameter was determined using open source software ImageJ. The resulting average nanofibers diameter for various concentration $\mathrm{SM}$ of $0 \%, 2 \%, 4 \%$ and $6 \%$ were $(460.17 \pm 128.32),(348 \pm 32.62),(486.73 \pm 122.64)$ and $(477.10 \pm 142.51)$ respectively and the nanofibre size diameter distribution is shown in Figure 2. It was found that the SM addition up to $2 \%(\mathrm{w} / \mathrm{v})$ noticeable reduced average size diameter and improved the uniformity of that membrane (Figure 2(b)). Yet, an increase of SM concentration ( $4 \%$ and $6 \% \mathrm{w} / \mathrm{v})$ reduced their uniformity and increased their average size diameter (Figure 2(c) dan (d)). The changing of solution viscosity due to the SM addition may associated to the change in the average ûbre diameter. The optimum viscosity has been reached at $2 \%$. In contrast to this, in usual, the increase of viscosity of the polymer solution resulted in larger fiber
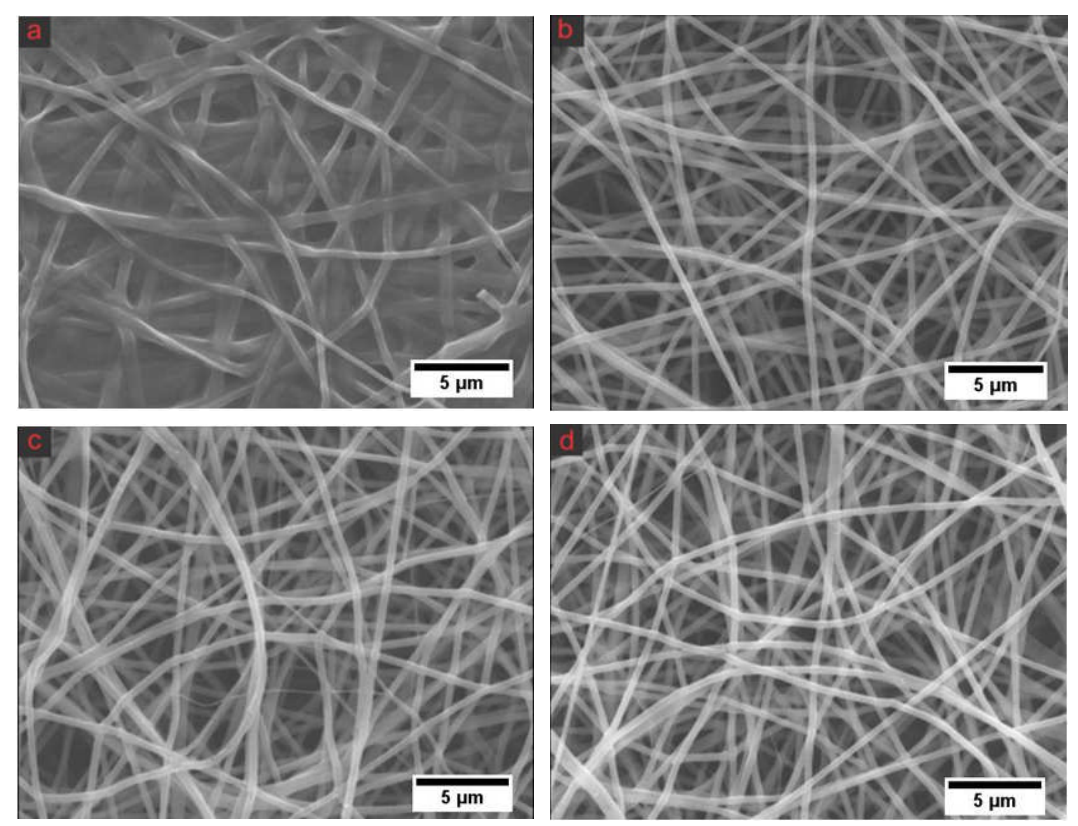

Figure 1. SEM images of nanofibre PVA/SM morphologies at the various concentration of SM (a). $0 \%$ (b). $2 \%$ (c). $4 \%$ and (d). $6 \%$. 

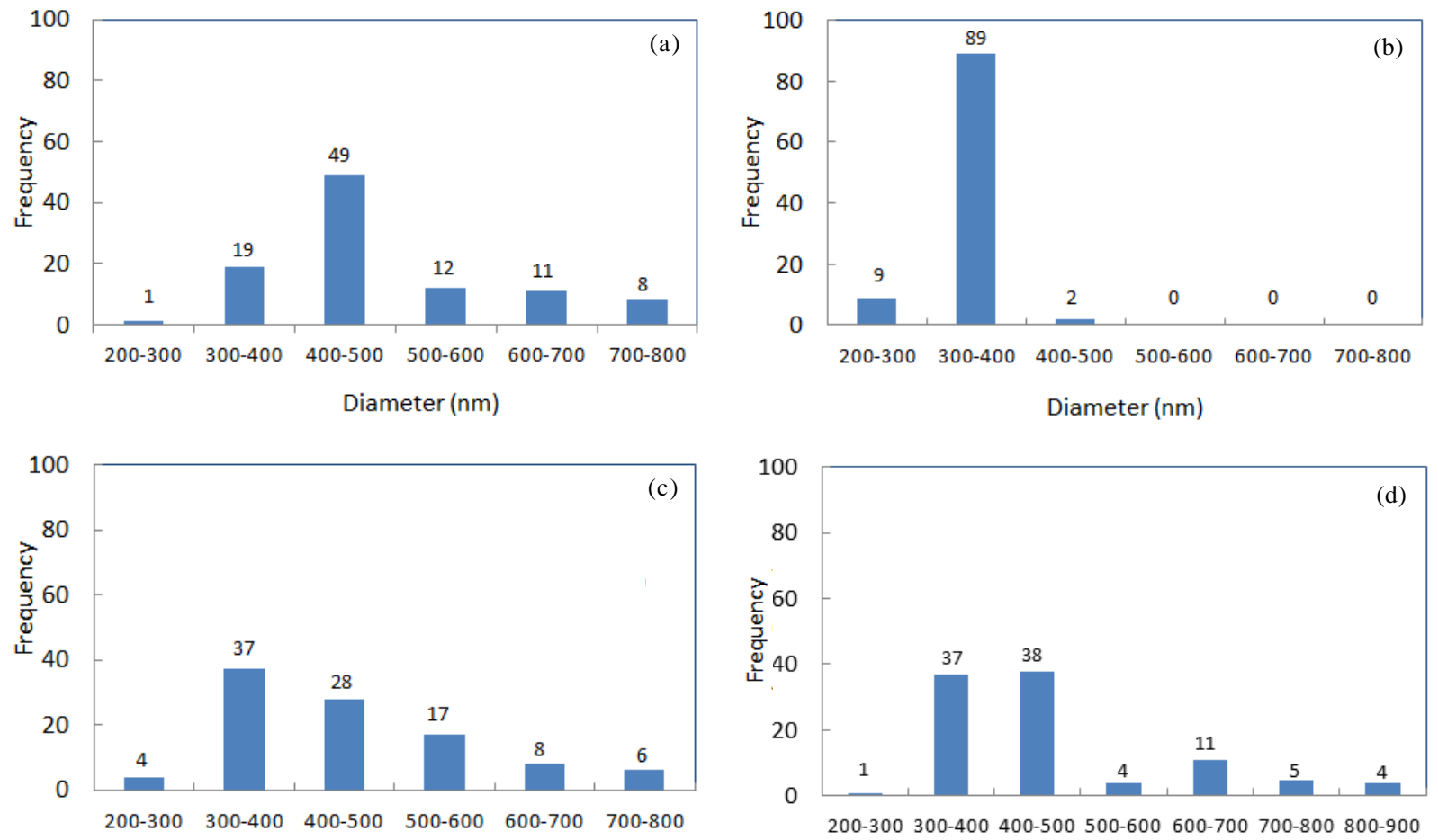

Figure 2. The nanofibres PVA/SM size diameter distribution at various concentration of SM: (a). $0 \%$, (b). $2 \%$, (c). $4 \%$ and (d). $6 \%$
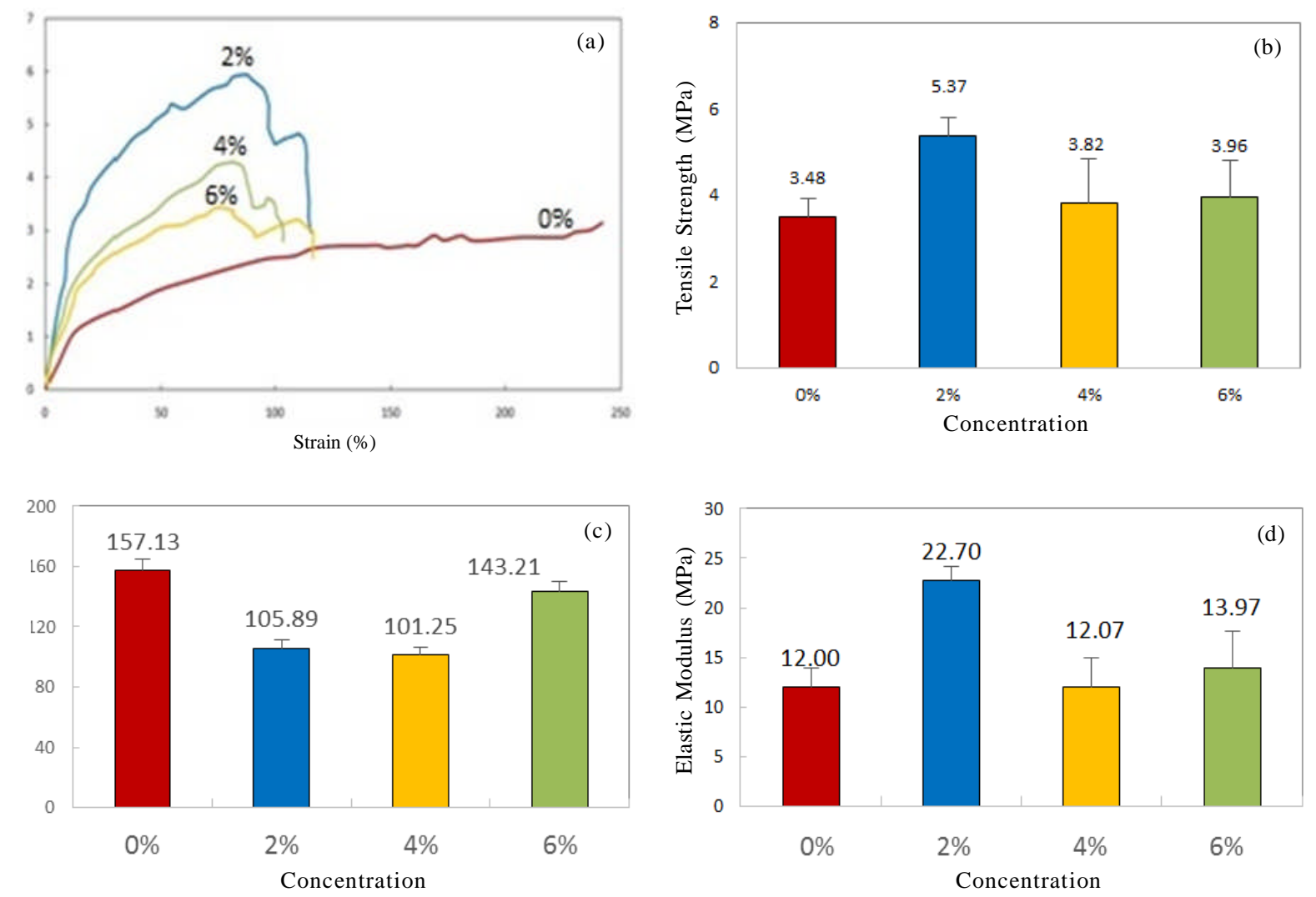

Figure 3. Tensile properties of composite electrospun PVA/SM nanofiber membrane (a). stress-strain curve, (b). tensile strength, (c). strain and (d). the elastic modulus.

size [13]. Average size fibre diametre fabricated in this study were still larger than that of the previous study conducted by Meilani et al. which is in range of
100-300 nm [10]. Although the smaller diameter of continued nanobres with minimum number of beads were produced at voltage of $23 \mathrm{kV}$, beads were mostly 
observed on their fabricated nanofibre membranes and nanofibres in discontinued form were produced at higher voltage.

The tensile properties of composite electrospun PVA/SM nanofiber membrane including stress strain curve, strength, strain and the elastic modulus are shown in Figure 3. The mechanical properties for wound dressing materials are considered to be important because these materials need certain tensile strength, ûexibility and elastic properties for handling and replacement. Stress-stain curve of the pure PVA (PVA/SM 0\% (w/v)) shows typical stress- strain curve of polymeric material which possess low in tensile strength and very large of the elongation.

Generally, the addition of SM into the PVA solution altered behavior of their stress strain curve. Their ultimate tensile stresses were clearer and the lines representing elastic behavior more erect than that of the pure PVA (Figure 3(a)), yet their elongation/strain were reduced significantly (Figure 3(c)). The PVA/SM $2 \%(\mathrm{w} / \mathrm{v})$ achieved the highest value of tensile strength $(5.37 \mathrm{MPa})$ followed by that of $6 \%(3.96 \mathrm{MPa})$, $4 \%(3.82 \mathrm{MPa})$ and $0 \%(\mathrm{w} / \mathrm{v})(3.48 \mathrm{MPa})$ as depicted in Figure 3(b). The elastic modulus of the nanofibre membrane presented the same behavior to the tensile strength (Figure 3(d)).

The drastic increase of the tensile strength and the modulus of the $2 \%(\mathrm{w} / \mathrm{v}) \mathrm{PVA} / \mathrm{SM}$ were associated to the average nanofibre size diameter in which smaller size diameter resulting in higher stress being held due to higher number nanofibre being stacked per unit volume. In addition its size diameter is more uniform than those of the others (Figure 2(b)).

The results indicated that the tensile strength could be tailored by selecting the appropriate parameter. However, these fundings demonstrated that these PVA/SM nanofibre membrane possess tensile strength that is still a half of that of commercial microfibrous dressings, which have tensile strengths on the order of $10 \mathrm{MPa}$ [13]. Therefore, the present work has high lighted the possibility of manufacturing PVA/SM nanofibre membrane with the potential achieving tensile properties requirement upon further optimizing the processing parameter.

\section{CONCLUSION}

The current study has successfully demonstrated the potential manufacturethe PVA/SM nanoûbre membrane beads-free by electrospinning technique. The addition of snail mucin into the solution affects the fiber size diameter leading to control tensile properties of the membrane. Optimum tensile properties was achieved on the composition of $2 \% \mathrm{SM}$ (5.37 MPa). The nanofiber membranes being developed are likely to show great potential as a wound dressing materials. In future study it will be designed to explore in detail the effect of processing parameter on the mechanical properties and preclinical behavior of the membrane.

\section{ACKNOWLEDGMENT}

The authors wish to thank Universitas Muhammadiyah Yogyakarta (UMY) for the funding and Mr Kunto Wadono for his expertise to develop the electrospinning machine.

\section{REFERENCES}

[1]. M. Abrigo, McArthur SL and Kingshott P. "Electrospun Nanofibers as Dressings for Chronic Wound Care: Advances, Challenges, and Future Prospects". Macromolecular Bioscience, vol. 14, pp. 772-792, 2014.

[2]. K. A. Rieger, Nathan P. Bircha and Jessica D. Schiffman. "Designing Electrospun Nanofiber Mats to Promote Wound Healing-a Review". Journal of Materials Chemistry B, vol. 1, pp. 45314541, 2013.

[3]. M. Koosha and H. Mirzadeh. "Electrospinning, Mechanical Properties, and Cell Behavior Study of Chitosan/PVA Nanofibers". Journal of Biomedical Materials Research Part A, vol. 103, pp. 3081-3093, 2015.

[4]. M. Gizaw, Thompson J, Faglie A, Lee SY, Neuenschwander P5 and Chou SF. "Electrospun Fibers as a Dressing Material for Drug and Biological Agent Delivery in Wound Healing Applications”. Bioengineering, vol. 5, pp. 9, 2018.

[5]. M. Wang, A.K. Roy, and T. J. Webster. "Development of Chitosan/Poly(Vinyl Alcohol) Electrospun Nanofibers for Infection Related Wound Healing". Frontiers in Physiology, vol. 7. 2017.

[6]. C.-H. Yao, JY. Yeh, YS. Chen, MH. Li and CH. Huang. "Wound-healing Effect of Electrospun Gelatin Nanofibres Containing Centella Asiatica Extract in a Rat Model". Journal of Tissue Engineering and Regenerative Medicine, vol. 11, pp. 905-915, 2017.

[7]. A. M. Abdelgawad, et al. "Antimicrobial Wound Dressing Nanofiber Mats from Multicomponent (Chitosan/ Ag -NPs/ Polyvinyl Alcohol) Systems". Carbohydrate Polymers, vol. 100, pp. 166-178, 2014.

[8]. L. B. Etim, C. Aleruchi and G A. Obande. "Antibacterial Properties of Snail Mucus on Bacteria Isolated from Patients with Wound Infection". British Microbiology Research Journal, vol. 11, pp. 1-9, 2016.

[9]. A. S. Harti, S. D. Sulisetyawati, A. Murharyati, M. Oktariani and I. B. Wijayanti. "The Effectiveness of Snail Slime and Chitosan in Wound Healing”. International Journal of Pharma Medicine and Biological Sciences, vol. 5, pp. 76, 2016. 
[10]. D. K. P. Meilanny, Pranjono and D. Hikmawati. "Electrospining Methode to Synthesize Compositebased on Alginate-Polyvinyl Alcohol with Addition of Snail (Achatina Fulica)". Proceeding on the Scientific Meeting and Presentation on Accelerator Technology and Its Applications, 2015.

[11]. D.-N. Yu, D.Tian and J.H. He. "Snail-Based Nanofibers," Materials Letters, vol. 220, pp. 5-7, 2018.
[12]. A. J. Hassiba, M.E. El Zowalaty, G.K. Nasrallah, T.J. Webster, A.S. Luyt, A.M. Abdullah, A.A. Elzatahry. "Review of Recent Research on Biomedical Applications of Electrospun Polymer Nanofibers for Improved Wound Healing". Nanomedicine, vol. 11, pp. 715-737, 2016.

[13]. V. Leung, R. Hartwell, H. Yang, A. Ghahary and F. Ko. "Bioactive Nanofibres for Wound Healing Applications". Journal of Fiber Bioengineering and Informatics, vol. 4, pp. 1-14, 2011. 